\title{
Zdrowy las potrzebuje chorych drzew
}

\author{
JERZY SZWAGRZYK
}

\begin{abstract}
SzWAGRZYK, J. 2020. A healthy forest needs diseased trees. Fragmenta Floristica et Geobotanica Polonica 27(1): 5-15. Kraków. e-ISSN 2449-8890, ISSN 1640-629X.

ABstract: Foresters in Poland have accepted the presence of coarse woody debris (CWD) in managed forests, but there is still a tendency to remove any diseased tree from the forest stand as soon as possible. Trees invaded by bark beetles or infested by pathogenic fungi are considered a threat to forest health. That approach is typical for timber-oriented forest management. In Poland, where multifunctional forestry is a declared policy in all forests belonging to the National Forests Enterprise, the rules for managing and protecting forest stands are uniform throughout the country. This does not allow some diseased or malformed specimens to be spared during forestry work as prospective habitat trees and as future sources of CWD. Without relaxation of the rules concerning sanitary cutting, it will be difficult to maintain or increase the current amount of CWD. There is no point in sparing diseased or injured trees in forest areas that are of no great value for recreation or conservation, where timber production is the priority, but in areas where recreation and conservation of biodiversity are of high value the rules should be changed to allow the number of habitat trees and the amount of CWD to increase.
\end{abstract}

KEY WORDS: coarse woody debris, forest management, habitat trees, near-natural silviculture, sanitary cuttings, timber production

J. Szwagrzyk, Katedra Bioróżnorodności Leśnej, Uniwersytet Rolniczy im. Hugona Kołtataja w Krakowie, al. 29 Listopada 46, 31-425 Kraków,Polska; e-mail: rlszwagr@cyf-kr.edu.pl

\section{WSTĘP}

Martwe drzewa w lesie są u nas zwykle opisywane i inwentaryzowane jako ,martwe drewno". Budzi to różnego rodzaju kontrowersje. Jedni wywodzą, że drewno jest to tkanka złożona z naczyń lub cewek, które są, technicznie rzecz ujmując, komórkami martwymi; zatem każde drewno jest martwe z definicji. Inni z kolei wskazują, że to, co znajdujemy w lesie, to zazwyczaj nie całe martwe drzewa, ale ich fragmenty; zatem trudno nazwać to inaczej niż „martwym drewnem”. Anglosasi mają z kolei swój termin CWD, czyli coarse woody debris (HARMON i in. 1986), który niektórzy polscy autorzy tłumaczą jako ,gruby rumosz drzewny" (WYŻGA i in. 2012). O ile jednak dla badacza zajmującego się transportem rumoszu skalnego w korytach rzek termin ,rumosz drzewny” jest całkowicie naturalny i zrozumiały, to trudno oczekiwać, aby określenie to mogło przyjąć się w leśnictwie. Pozostaje zatem to nie całkiem poprawne „martwe drewno”, dla którego nie znaleźliśmy dotąd dobrej alternatywy. 
Terminologia, której używamy, wpływa na postrzeganie i rozumienie samego zjawiska. Jeżeli mówimy o martwym drewnie w lesie, to można sobie wyobrazić, że sposobem na zwiększenie jego zasobów w lesie mogłoby się okazać wywożenie grubszych odpadów drzewnych do lasu. Albo, żeby posłużyć się bardziej skrajnym przykładem, wywożenie do lasu starych drewnianych mebli - to też jest „,martwe drewno”. Oczywiście, każdy leśnik uzna takie pomysły za absurdalne, a i większość laików chyba intuicyjnie wyczuje, że wcale nie o to chodzi. Nie znaczy to jednak, że nie ma problemu; termin, którym się posługujemy nie wskazuje wyraźnie na istotę tego, co chcemy chronić. A chodzi o naturalne procesy i o zagrożone gatunki grzybów, zwierząt i roślin (LINDENMAYER \& FRANKLIN 2002; GuTOWSKI $i$ in. 2004). Ci, którzy mierzą i liczą metry sześcienne „martwego drewna” przypadające na hektar lasu, niekoniecznie zdają sobie z tego sprawę. Zaś informacje, które uzyskujemy z tego typu inwentaryzacji, mają bardzo ograniczoną wartość.

W toku długotrwałych dyskusji i sporów, dotyczących obecności i roli martwych drzew w lasach, osiagnięty został swoisty konsensus. Leśnicy zaakceptowali obecność martwych drzew (CZEREPKO 2008; REFEROWSKA-CHODAK 2014), a kolejne inwentaryzacje potwierdzają, że zasoby martwych drzew w naszych lasach powoli się zwiększają (WISL 2018). Skąd bierze się „martwe drewno” w lesie nie jest jednak całkiem jasne. Inwentaryzacje wskazują, że większość tego drewna jest słabo rozłożona, leży zatem w lesie od niedawna. Jest więcej niż prawdopodobne, że większa jego część pozostała w lesie po wystąpieniu naturalnych zaburzeń (MILAD i in. 2011; SzWAGRZYK 2014), kiedy do usunięcia jest bardzo dużo masy drzewnej i siłą rzeczy część z niej pozostaje nie wywieziona. Nie mamy jednak co do tego pewności; dane są w gruncie rzeczy wyrywkowe. W związku z tym, że inwentaryzujemy „martwe drewno” co dziesięć lat, nie mamy ciągłości obserwacji. Prac naukowych dokładnie śledzących to, co dzieje się z pniami martwych drzew w europejskich lasach jest niewiele (CHRISTENSEN $i$ in. 2005; HoleKsa i in. 2008; AAKAla 2010), a i tak większość z nich została wykonana w parkach narodowych lub w rezerwatach.

\section{PROBLEMY ZACHOWANIA CIĄGŁOŚCI WYSTĘPOWANIA MARTWYCH DRZEW W LASACH}

Zasoby martwego drewna w lesie kształtują dwa procesy: zamieranie drzew i rozkład martwych pni. W lasach gospodarczych dochodzi do tego wywożenie martwych drzew oraz pozostawianie pniaków po ściętych drzewach, a także obciętych wierzchołków drzew czy grubych gałęzi. Aby utrzymać zasoby na określonym poziomie, konieczny jest dopływ określonej ilości martwych pni w miarę jak te, które były już wcześniej, ulegają rozkładowi (HolEKSA $\mathrm{i}$ in. 2014). Martwe drzewa w lesie rozkładają się w ciągu kilkunastu do kilkudziesięciu lat (HoleKsa i in. 2008; HerRmAnN \& BAUHus 2013), dlatego utrzymanie obecnego poziomu zasobów martwych drzew w naszych lasach - nie mówiąc już o jego wzroście - nie jest wcale pewne. Nie ma też zgody co do tego, skąd mają się brać martwe drzewa w lesie zagospodarowanym. Wymogi sanitarne nakazywały bowiem do niedawna usuwanie z lasu praktycznie wszystkich drzew chorych i obumierających (ZASADY HoDOwLi LASU 2012). W lesie można było zostawiać posusz jałowy, natomiast posusz czynny należało usunąć. Ale skąd się bierze posusz jałowy? To martwe drzewa, które zostały już opuszczone 
przez owady kambio- i ksylofagiczne, albo w ogóle nie zostały zasiedlone i nie są już atrakcyjnym materiałem dla tych owadów. Można zatem powiedzieć, że każde martwe drzewo w lesie było efektem czyjegoś zaniedbania. Nowe regulacje w tym względzie stwarzają możliwość pozostawiania drzew chorych i posuszu czynnego, ale tak, żeby nie spowodować zagrożenia gradacją owadów kambiofagicznych. Jest zatem taka możliwość, ale nie ma takiego obowiązku. Pozostawianie takich drzew wymaga sporej asertywności zważywszy na fakt, że przyzwyczajenia inspektorów kształtowały się pod wpływem dawnych instrukcji, a znajomość nowych przepisów nie jest wcale powszechna.

W celu utrzymania zasobów martwych drzew w lasach na obecnym poziomie, musielibyśmy się zgodzić na to, żeby pozostawianie drzew chorych i posuszu czynnego zachodziło nadal z nie mniejszą częstością niż miało to miejsce do tej pory. Wobec zmieniającej się technologii inwentaryzacji zasobów leśnych i kontroli stanu lasu, polegającej w coraz większym stopniu na zastosowaniu metod zdalnych, wykrywanie drzew chorych i zamierających może się wkrótce okazać szybsze i bardziej skuteczne niż obecnie. W ten sposób szanse na przetrwanie w lesie ,,posuszu czynnego” mogą się nawet zmniejszyć, a w efekcie zasoby martwych drzew w lasach mogą się z czasem obniżyć. Aby tak się nie stało, potrzebne są szkolenia i ciągła edukacja służby leśnej. To jest jednak znacznie trudniejsze do zrealizowania niż sama nowelizacja przepisów.

Warto zwrócić uwagę na fakt, że oprócz martwych drzew w różnych stopniach rozkładu, bardzo ważną rolę w funkcjonowaniu ekosystemu leśnego odgrywają drzewa chore i uszkodzone. To spośród nich rekrutują się tak zwane „drzewa mikrosiedliskowe” (habitat trees), będące miejscem występowania dużej grupy organizmów, od grzybów przez owady, ptaki aż do ssaków (KRAUS i in. 2016). Niekiedy procesy chorobowe są rozciągnięte na dziesięciolecia i może zdarzyć się tak, że drzewa chore żyją dłużej niż sąsiednie drzewa zdrowe. W wielu przypadkach „drzewa mikrosiedliskowe” mają martwe konary lub ich fragmenty, czy też obumarłe kawałki pnia wokół dziupli; w taki oto sposób, pewna część „martwego drewna” wmontowana jest w drzewa żywe. Oczywiście nie ujmuje się tego w żadnych pomiarach, nie jest to zapewne wiele pewnie nie zmieniłoby to ogólnego bilansu. Warto jednak odnotować fakt, że część gatunków związanych z martwym drewnem zasiedla też drzewa żywe; granica między drzewami martwymi i żywymi nie zawsze jest ostra i wyraźna.

\section{SPRZECZNOŚCI W OBRĘBIE GOSPODARKI LEŚNEJ}

Gospodarka leśna w środkowej Europie, a szczególnie w Polsce, ma charakter hybrydowy, czerpie z dwóch różnych źródeł inspiracji (ANDERSSON i in. 2004). Z jednej strony jest to tradycja gospodarowania w lesie, rozumianego jako sterowanie naturalnymi procesami, a z drugiej strony istnieje nurt surowcowy. Nurt polegający na sterowaniu naturalnymi procesami (DiACI 2006) jest obecny w leśnictwie od samego początku, przejawia się obecnie przede wszystkim w ramach podejścia ekosystemowego, czy też „półnaturalnej hodowli” (BRZEZIECKI 2008). W tak pojmowanej gospodarce leśnej, duży nacisk jest położony na dopasowanie składu gatunkowego drzewostanów do warunków siedliska; odnowienie 
lasu jest głównie naturalne, a pozyskiwanie drewna jest dokonywane przy pomocy złożonych rębni (Diaci 2006).

To jednak nie wystarcza. Jeżeli mamy zarządzać ekosystemem leśnym, a nie tylko hodować drzewostany wysokiej jakości, musi się w gospodarce leśnej znaleźć miejsce dla tych procesów i zjawisk, które są niezbędne w ekosystemie leśnym. Należą do nich m.in. przepływ energii i obieg materii, obejmujący zamieranie drzew i ich rozkład, procesy glebotwórcze z akumulacją węgla w glebie, procesy naturalnej selekcji w populacjach czy funkcjonowanie populacji roślinożerców, drapieżników i pasożytów. Z tym bywa już gorzej; o ile dopasowanie składu gatunkowego do warunków siedliska czy stosowanie złożonych rębni jest w polskim leśnictwie powszechnie akceptowane, to na przykład z naturalną selekcją pogodzić się jest już trudniej. Nadal dominuje w leśnictwie przekonanie, że są w lesie drzewa dobre i drzewa złe; te pierwsze należy popierać, te drugie eliminować. Nawet w warunkach stosowania złożonych rębni w wielogatunkowych drzewostanach trudno o refleksję, że drzewa, które rosną wolniej lub bardziej krzywo, mogą mieć cechy, które z perspektywy trwałości ekosystemu leśnego mogą się kiedyś okazać ważne i cenne.

Nie można jednak właściwie zarządzać ekosystemem leśnym, mając aparat pojęciowy ukształtowany przez leśnictwo surowcowe, w którym choroby i zamieranie drzew to zagrożenie dla drzewostanu, zwierzęta roślinożerne to szkodniki, a rozkładające się drewno to przejaw marnotrawstwa. Leśnictwo surowcowe to nurt inspirowany niewattpliwymi sukcesami szeroko pojętego rolnictwa, próbujący stosować w lesie wypracowane w rolnictwie technologie i procedury. Nurt ten charakteryzuje: selekcja drzew ukierunkowana na szybki wzrost za młodu, zwalczanie roślinożernych owadów i patogenów grzybowych oraz daleko posunięta mechanizacja prac leśnych. Nurt ten współistnieje w polskim leśnictwie z nurtem półnaturalnej hodowli lasu w sposób na ogół zgodny. Przyjęło się, że gospodarka oparta na hodowli lasu bliskiej naturze dominuje w górach i na żyznych siedliskach, co w sumie stanowi mniej niż jedną czwartą powierzchni polskich lasów. Nurt surowcowy dominuje na siedliskach uboższych na niżu, gdzie przeważają jednowiekowe drzewostany zdominowane przez sosnę zwyczajną.

Oczywiście współistnienie tych dwóch nurtów nie ogranicza się do Polski czy do środkowej Europy; jednak w wielu krajach równowagę między nimi osiąga się poprzez przestrzenne rozdzielenie priorytetowych funkcji (EDWARDS i in. 2014). W lasach, mających pełnić głównie funkcje ochronne i rekreacyjne, zarządza się naturalnymi procesami w terenach, gdzie priorytetem jest produkcja drewna, stosuje się cały zestaw metod i procedur wypracowanych w rolnictwie: selekcję materiału genetycznego, nawożenie mineralne, chemiczne zwalczanie owadów czy patogenicznych grzybów. W sposób najpełniejszy nurt surowcowy jest realizowany na plantacjach drzew szybko rosnących.

W Polsce, gdzie panuje ,wielofunkcyjna gospodarka leśna” (DrOzDOwsKi 2008), poszczególne priorytety nie zostały wyraźnie rozdzielone; w każdym lesie trzeba przestrzegać tych samych reguł i stosować te same procedury, opisane w Zasadach Hodowli Lasu (2012) czy w Instrukcji Ochrony Lasu (2012) oraz w ich późniejszych nowelizacjach. Ma to swoje negatywne konsekwencje. W obszarach gdzie przeważa ,podejście ekosystemowe" wymusza to stosowanie rozwiązań typowych dla podejścia surowcowego. Usuwanie wszystkich drzew chorych i zamierających, zwane zwykle ,utrzymaniem właściwego stanu 
sanitarnego lasu", jest zwykle najskuteczniejszym sposobem przeciwdziałania rozprzestrzenianiu się infekcji grzybowych czy gradacji owadów kambiofagicznych. Jest to postępowanie sensowne i słuszne wszędzie tam, gdzie priorytetem jest produkcja surowca drzewnego. Jego efektem ubocznym jest las pozbawiony praktycznie drzew chorych i zamierających, w którym martwe drewno reprezentuja głównie pniaki po ściętych drzewach oraz grubsze gałęzie. Czy jednak jest to właściwa metoda postępowania w nurcie ekosystemowym, tam gdzie las ma pełnić głównie funkcje rekreacyjne lub ochronne? Nie, ale nie jest to sformułowane wyraźnie ani w Zasadach Hodowli Lasu (2012), ani w Instrukcji Ochrony Lasu (2012) oraz w ich znowelizowanych wersjach.

Narzucanie jednolitych reguł dla całej gospodarki leśnej odbija się także niekorzystnie na warunkach produkcji surowca drzewnego. W wielu miejscach, gdzie funkcje rekreacyjne i ochronne odgrywają mniejszą rolę i gdzie priorytetem powinna być produkcja drewna, pojawia się też presja na to, aby w lesie pozostawiać więcej martwych drzew. Nie ma to pewnie większego przyrodniczego sensu; nie znamy dokładnie możliwości dyspersji gatunków związanych z martwymi drzewami, ale na ogół przyjmuje się, że ich zdolność kolonizowania nowych siedlisk jest bardzo ograniczona (GuTOwsKI i in. 2004). Jeżeli na jakimś terenie nie ma gatunków związanych z martwymi drzewami, to pozostawianie dla nich martwych pni będzie zapewne działaniem nieskutecznym - pnie wprawdzie się z czasem rozłożą, ale prawdopodobnie nie zostaną zasiedlone przez rzadkie i chronione gatunki. Brak przestrzennego rozdziału priorytetowych funkcji lasu sprawia, że traci na tym zarówno nurt ekosystemowy, jak i nurt surowcowy (RYKOwSKI 2013).

\section{PROPOZYCJE UNIKNIĘCIA KONFLIKTÓW}

W przypadku lasów z dominującą funkcją rekreacyjną i ochronną, warto byłoby zdefiniować progi ilościowe drzew zamierających i martwych, powyżej których zabiegi sanitarne powinny być bezwzględnie stosowane, ilości dopuszczalne, które można by w lesie pozostawiać, oraz ilości minimalne, poniżej których nie wolno byłoby schodzić. Lektura obecnie obowiązującej Instrukcji Ochrony Lasu (2012 oraz późniejsze nowelizacje) wskazuje na możliwość pozostawiania takich drzew; nie jest to jednak obowiązkowe, nie zaproponowano też żadnych progów ilościowych. Co więcej, w wypowiedziach urzędników wysoko postawionych w hierarchii leśnej, podkreślana jest konieczność szybkiego wyszukiwania i usuwania chorych drzew (SZCZERBicKi 2020). W rezultacie chore i zamierające drzewa zasilają pulę drzew martwych na ogół wtedy, gdy nie zostaną zauważone przez leśnika. Podobnie jest $\mathrm{z}$ drzewami dziuplastymi; przepisy zalecają ich pozostawianie, ale żeby powstała w drzewie dziupla, najpierw musi być ono zainfekowane przez grzyby (CocKLE \& MARTIN 2011). Szansa na powstanie dziupli pojawia się zatem wtedy, kiedy infekcja grzybowa nie zostanie odpowiednio wcześnie wykryta, a zainfekowane drzewo nie zostanie usunięte $\mathrm{w}$ trakcie prowadzenia trzebieży. W wielu przypadkach tak się dzieje, trudno jednak opierać politykę ochrony różnorodności biologicznej na założeniu, że większość leśników w terenie świadomie podejmie ryzyko, które jest wprawdzie dopuszczone, ale którego konsekwencje mogą być dla nich bardzo niekorzystne. 
W dziedzinie nauk leśnych podjęto już próby ilościowego wyznaczania progów, poniżej których zamieranie drzew nie powinno stanowić przedmiotu troski ani przyczyny interwencji leśnika. Zrobił to między innymi Paul Manion, autor kluczowego podręcznika z zakresu chorób drzew leśnych Tree disease concepts (MANION 1981). Zdaniem MANIONA (2003), liczba drzew zamierających w ciągu danego okresu powinna być porównywana $\mathrm{z}$ poziomem rekrutacji niezbędnym dla utrzymania udziału danego gatunku $\mathrm{w}$ drzewostanie w określonym zakresie. Podstawą do ingerencji byłoby stwierdzenie poziomu śmiertelności przekraczającego wielkości typowe dla danego gatunku w danych warunkach siedliskowych. Podobne próby, oparte na koncepcji dynamicznej równowagi populacji, były również podejmowane przez innych badaczy (CANHAM 2014; BRZEZIECKI i in. 2016).

Populacje drzew leśnych mogą wcale nie osiagać stanu dynamicznej równowagi, szczególnie teraz, wobec zmian globalnych (JAROSZEWICZ i in. 2017). Tym niemniej jest to pewien racjonalny punkt odniesienia, na pewno bardziej uzasadniony niż przekonanie, że cały proces eliminacji drzew od etapu młodnika ma być realizowany poprzez zabiegi pielęgnacyjne. Istotą tych zabiegów - oprócz zapewniania drzewom odpowiedniej przestrzeni i zasobów - jest dokonywanie selekcji pod względem jakości techniczno-hodowlanej. Wszystkie osobniki zdeformowane lub wykazujące symptomy chorobowe są z zasady usuwane w trakcie prowadzenia czyszczeń czy trzebieży. Z punktu widzenia hodowli lasu, ukierunkowanej na produkcję surowca drzewnego wysokiej jakości, jest to postępowanie jak najbardziej prawidłowe. Zarazem jest to jednak głęboka ingerencja w procesy naturalnej selekcji, zachodzace w populacjach drzew (FInKELDEY \& ZieHe 2004; PAFFETTI i in. 2012).

Bez ingerencji człowieka w drzewostanach również następuje eliminacja osobników; nazywana jest samoprzerzedzaniem się populacji (self-thinning). Literatura poświęcona temu zjawisku jest bardzo obszerna (ZEIDE 1987; PrETzSCH 2006; WADE 2018). W gruncie rzeczy, stosowane w leśnictwie czyszczenia i trzebieże niejako wyprzedzają proces samoprzerzedzania się populacji poprzez usuwanie drzew, które zostały zdominowane i w niedługim czasie pewnie same zamarłyby. To jednak tylko jedna strona zabiegów czyszczeń i trzebieży. W ramach tych zabiegów eliminuje się również drzewa, które w procesie naturalnej selekcji byłyby najprawdopodobniej wśród zwycięzców. Usuwa się tak zwane rozpieracze, czyli drzewa, które w młodym wieku uzyskały przewagę konkurencyjną nad sąsiadami i znacznie górują nad nimi wysokością. Usuwa się też drzewa odbiegające od pożądanego kształtu - czyli osobniki z rozwidlonym pniem, silnie wygięte u podstawy czy ze złamanym wierzchołkiem. Gdyby nie selekcja sztuczna prowadzona w trakcie czyszczeń i trzebieży, wiele z tych drzew tworzyłoby okap drzewostanu, a niektóre z nich stałyby się drzewami mikrosiedliskowymi (KraUs i in. 2016).

Selekcja drzew, którą leśnicy prowadzą w lesie, jest ukierunkowana na uzyskanie największej ilości surowca wysokiej jakości. Kształtowane w ten sposób lasy mają wiele zalet, ale nie dzieje się to bez skutków ubocznych. Przekonanie, że jeżeli usuniemy z drzewostanu wszystkie rozpieracze, drzewa krzywe i rozwidlone to uzyskamy same pozytywne skutki dla ekosystemu leśnego, jest błędne. To błędne przekonanie wynika z rozciagnięcia kryteriów leśnictwa surowcowego na zarządzanie ekosystemem leśnym. W przyrodzie nie jest tak, że można osiągnąć wszystko nie tracąc nic (GRIME 1979; STEARNs 1992). Tak jest tylko w popularnych wyobrażeniach na temat „,wielofunkcyjnej gospodarki leśnej”, która niesie 
ze sobą same korzyści, a nie przynosi żadnych strat. W realnym świecie istnieją jednak konflikty i funkcjonuje zasada „coś za coś”. Gospodarka leśna będzie musiała się z tym problemem zmierzyć.

Polski model wielofunkcyjnej gospodarki leśnej jest oparty na niesformułowanym w sposób otwarty założeniu, że można pogodzić ze sobą różne funkcje lasu w sposób nie powodujący upośledzenia żadnej z nich (DROzDOWSKI 2008). Jednak tylko produkcja surowca drzewnego jest mierzona i monitorowana w sposób ilościowy. Pozostałe efekty gospodarowania w lesie nie są oceniane w sposób tak rygorystyczny; mają być osiągane przy okazji realizowania funkcji produkcyjnej. Panuje przekonanie, że prowadzona w sposób poprawny gospodarka leśna w niczym nie zaprzecza realizacji funkcji rekreacyjnej lasu ani nie upośledza jego licznych funkcji środowiskowych. Pojawiające się coraz częściej konflikty świadczą jednak o tym, że model wielofunkcyjnej gospodarki leśnej nie wszędzie sprawdza się równie dobrze.

Jeżeli chcemy mieć martwe drzewa w lasach gospodarczych, musimy mieć również drzewa chore i zamierające. Będzie to wymagało istotnej zmiany podejścia do zasad hodowli i ochrony lasu. Nie ma możliwości (ale też nie ma potrzeby) wprowadzania tych zmian w sposób jednolity we wszystkich lasach zarządzanych przez Administrację Lasów Państwowych. Produkcja surowca drzewnego narzuca mocne ograniczenia w tym względzie. Obowiązujące obecnie zasady hodowli lasu są sformułowane tak, żeby w sposób optymalny wykorzystywać powierzchnię leśną do hodowli zdrowych drzew o wysokiej wartości technicznej. Drzewa chore lub ukształtowane w sposób odbiegający od standardu nie mieszczą się w modelu realizowanej u nas obecnie gospodarki leśnej. Jeżeli gdzieś są, to jest to zwykle efekt dawnej gospodarki w lasach, znacznie gorzej zorganizowanej niż gospodarka współczesna, niekiedy nawet prowadzonej w sposób plądrowniczy. Wiele okazałych drzew, które dzisiaj podziwiamy w naszych lasach, wyrosło w warunkach luźnego zwarcia po rabunkowych niekiedy wyrębach w czasie wojen i wstrząsów społecznych w odległej przeszłości. Współcześni leśnicy takich drzew już po sobie nie zostawią.

Tam, gdzie względy produkcji surowca drzewnego nie są priorytetem, należałoby dopuścić pozostawianie w lesie drzew, które w bliskiej perspektywie dostarczą mikrosiedlisk nadrzewnych, a w dalszej perspektywie, po obumarciu, zwiększą zasoby drzew martwych. Przy utrzymującej się obecnie dużej przewadze przyrostu drzew nad pozyskaniem (SochA 2019), nie ma potrzeby optymalizowania produkcji surowca drzewnego zawsze i wszędzie. Mamy pewien margines swobody, który gospodarka leśna mogłaby wykorzystać dla wzmocnienia realizacji pozaprodukcyjnych funkcji lasu.

Wprowadzenie w lasach możliwości zróżnicowania reguł postępowania w zakresie ochrony lasu, czyli stworzenia możliwości lokalnego lub czasowego odstąpienia od potrzeby prowadzenia cięć sanitarnych, byłoby wyjściem naprzeciw postulatom przyrodników zainteresowanych utrzymaniem w lasach gatunków wymagających nadrzewnych mikrosiedlisk, jak również postulatom ludzi chcących widzieć w lasach stare, duże drzewa, niezagrożone wycięciem. Pozwoliłoby to na uniknięcie wielu konfliktów. Problem nie sprowadza się do dylematu: ciąć czy nie ciąć, pozyskiwać czy nie pozyskiwać? Według najnowszych danych przyrost masy drzewnej w polskich lasach jest obecnie znacznie większy, niż niegdyś zakładano. W efekcie pozyskuje się obecnie tylko około $60 \%$ rocznego przyrostu 
masy (Socha 2019). Skoro i tak pozostawiamy na pniu $40 \%$ rocznego przyrostu, to można by to zrobić w taki sposób, aby w tych $40 \%$ mieściło się jak najwięcej lasów o priorytetowych funkcjach rekreacyjnych i ochronnych. Oznaczałoby to z drugiej strony intensyfikację pozyskania w terenach, które pod względem ochronnym i rekreacyjnym odgrywają mniejsza rolę. Nie oznacza to, że mielibyśmy tam ciąć rabunkowo; wystarczyłoby pozyskiwać tam 80-90\% rocznego przyrostu, czyli prowadzić zrównoważoną gospodarkę leśną, w której pozyskanie równe jest przyrostowi. To z kolei pozwoliłoby w miejscach szczególnie cennych przyrodniczo pozyskiwać mniej niż 50\% przyrostu.

Wymagałoby to odejścia od sztywnych reguł, które krępują możliwość elastycznego dostosowania gospodarki leśnej do szybko zmieniających się warunków przyrodniczych, ekonomicznych i społecznych (SzWAGRZYK 2019). Reguły te sformułowano dawno temu, w zupełnie innych uwarunkowaniach. Przez kilka dziesięcioleci dobrze się sprawdzały - w dużej mierze zasługą ich konsekwentnego stosowania jest wzrost zasobności drzewostanów i widoczna poprawa ich struktury gatunkowej (WISL 2018). W obecnych warunkach reguły te, jeżeli traktowane są jako nienaruszalne, zaczynają generować problemy. Wielu leśników zdaje sobie z tego sprawę, stąd pojawiające się ostatnio postulaty bardziej elastycznego podejścia na przykład do kwestii wieku rębności (BORECKI 2019).

Oczekiwania względem lasu zmieniają się. Kiedyś dla większości ludzi odwiedzających lasy wystarczało, żeby las był zielony, pachniał żywicą i można było w nim zbierać jagody oraz grzyby. Obecnie coraz więcej ludzi odwiedzających lasy chciałoby w nich spotykać także stare i okazałe drzewa, związane z nimi gatunki ptaków, owadów, grzybów, porostów i mszaków. Wiele z tych gatunków nie występuje we wzorowo zagospodarowanych lasach. Potrzebne są dla nich enklawy, w których będą mogły przetrwać i gdzie będzie je można oglądać i podziwiać. Nie tylko w parkach narodowych i w rezerwatach, nie tylko w czasie wakacji. Także podczas popołudniowych spacerów po lesie, do którego można dojść na piechotę i nie trzeba tam jechać samochodem. Nie muszą to być rozległe naturalne lasy, bo tych zostało nam bardzo niewiele. Tym bardziej powinniśmy się zatroszczyć o to, co jeszcze mamy, nawet jeżeli są to pojedyncze egzemplarze starych, okazałych i mniej lub bardziej chorych drzew. Nie da się tego zrobić bez szerszego włączenia społeczeństwa w proces podejmowania decyzji o gospodarowaniu w lesie. Współczesne czysto formalne konsultacje przy przygotowaniu planów urządzania lasu będą musiały ustąpić podejściu partycypacyjnemu.

\section{LITERATURA}

AaKala T. 2010. Coarse woody debris in late-successional Picea abies forests in northern Europe: variability in quantities and models of decay class dynamics. - Forest Ecology and Management 260: 770-779.

Andersson F., Birot Y. \& Pärvinen R. (red.). 2004. Towards the sustainable use of Europe's forests - forest ecosystem and landscape research: scientific challenges and opportunities. - EFI Proceedings 49: $1-323$.

BORECKI T. 2019. Szanujmy prawo; O konfliktach wokół leśnictwa, postulatach aktywistów, a także nowej metodzie regulacji użytkowania rębnego rozmawiamy z prof. Tomaszem Boreckim z Wydziału Leśnego SGGW. - Głos Lasu 12: 18-21. 
BRZEZIECKI B. 2008. Podejście ekosystemowe i półnaturalna hodowla lasu (w kontekście zasady wielofunkcyjności lasu). - Studia i Materiały Centrum Edukacji Przyrodniczo-Leśnej w Rogowie 19: 41-54.

Brzeziecki B., Pommerening A., Miścicki S., Drozdowski S. \& Żybura H. 2016. A common lack of demographic equilibrium among tree species in Białowieża National Park (NE Poland): evidence from long-term plots. - Journal of Vegetation Science 27: 460-467.

CAnham C. D. 2014. Disequilibrium and transient dynamics: disentangling responses to climate change versus broader anthropogenic impacts on temperate forests of eastern North America. - W: D. A. Coomes, D. F. R. P. Burslem \& W. D. Simonson (red.), Forests and global change, s. 109-128. Cambridge University Press, Cambridge, UK.

Christensen M., Hahn K., Mountford E. P., Ódor P., Standovár T., Rozenbergar D., Diaci J., WijdeVEN S., MeYer P., Winter S. \& VRSKa T. 2005. Dead wood in European beech (Fagus sylvatica) forest reserves. - Forest Ecology and Management 210: 267-282.

COCKLE K. \& MARTIN K. 2011. Woodpeckers, decay, and the future of cavity-nesting vertebrate communities worldwide. - Frontiers in Ecology and the Environment 9(7): 377-382.

Czerepko J. (red.). 2008. Stan różnorodności biologicznej lasów w Polsce. s. 135. Instytut Badawczy Leśnictwa, Sękocin Stary.

DiACI J. (red.). 2006. Nature-based forestry in Central Europe. - Studia Forestalia Slovenica 126: 1-167.

DROZDOwSKI S. 2008. Leśne obszary funkcjonalne - założenia ideowe. - Studia i Materiały Centrum Edukacji Przyrodniczo-Leśnej 3(19): 11-20.

Edwards D. P., Gilroy J. J., Woodcock P., Edwards F. A., Larsen T. H., Andrews D. J. R., Derhé M. A., Docherty T. G. S., Hsu W. W., Mitchell S. L., Ota T., Williams L. J., Hamer K. C. \& WiLcove D. S. 2014. Land-sharing versus land-sparing logging: reconciling timber extraction with biodiversity conservation. - Global Change Biology 20: 183-191.

FinKELDEY R. \& ZiEHE M. 2004. Genetic implications of silvicultural regimes. - Forest Ecology and Management 197: 231-244.

Grime J. P. 1979. Plant strategies and vegetation processes. s. 222. John Wiley \& Sons, Chichester, UK.

Gutowski J., Bobiec A., Pawlaczyk P. \& Zub K. 2004. Drugie życie drzewa. s. 245. WWF Polska, Warszawa - Hajnówka.

Harmon M. E., Franklin J. F., Swanson F. J., Sollins P., Gregory S. V., Lattin J. D., Anderson N. H., Cline S. P., Aumen N. G., Sedell J. R., Lienkaemper G. W., Cromack K. \& Cummins K. W. 1986. Ecology of coarse woody debris in temperate ecosystems. - Advances in Ecological Research 15: $133-302$.

HERRMANN S. \& BAUHus J. 2013. Effects of moisture, temperature and decomposition stage on respirational carbon loss from coarse woody debris (CWD) of important European tree species. - Scandinavian Journal of Forest Research 28: 346-357.

Holeksa J., ZielonKA T. \& ŻYwIEC M. 2008. Modeling the decay of coarse woody debris in a subalpine Norway spruce forest of the West Carpathians, Poland. - Canadian Journal of Forest Research 38: 415-428.

HoleKsA J., ŻywIEC M. \& KUREK P. 2014. Ilość obumarłych drzew w lasach gospodarczych w związku z wymaganiami ochrony przyrody na obszarach Natura 2000 - od statycznego do dynamicznego podejścia. - Studia i Materiały Centrum Edukacji Przyrodniczo-Leśnej 41(4): 15-29.

InSTRUKCJa OCHRONy LASU. 2012. s. 124. Centrum Informacyjne Lasów Państwowych, Warszawa.

JARoszewicz B., Bobiec A. \& Eycott A. E. 2017. Lack of demographic equilibrium indicates natural, large-scale forest dynamics, not a problematic forest conservation policy - a reply to Brzeziecki et al. - Journal of Vegetation Science 28: 218-222. 
Kraus D., Bütler R., Krumm F., Lachat T., Larrieu L., Mergner U., Paillet Y., Rydkvist T., SCHUCK A. \& WINTER S. 2016. Catalogue of tree microhabitats - reference field list. s. 16. Integrate+ Technical Paper. Regional Office EFICENT, European Forest Institute, Freiburg, Germany.

LinDENMAYER D. B. \& FRANKLIN J. F. 2002. Conserving forest biodiversity: a comprehensive multiscaled approach. s. 351. Island Press, Washington.

Manion P. D. 1981. Tree disease concepts. s. xv + 399. Prentice-Hall, Englewood Cliffs, New Jersey.

Manion P. D. 2003. Evolution of concepts in forest pathology. - Phytopathology 93: 1052-1055.

Milad M., Schaich H., BÜrgi M. \& KonOld W. 2011. Climate change and nature conservation in Central European forests; A review of consequences, concepts and challenges. - Forest Ecology and Management 261: 829-843.

Paffetti D., Travaglini D., Buonamici A., Nocentini S., Vendramin G. G., Giannini R. \& Vettori C. 2012. The influence of forest management on beech (Fagus sylvatica L.) stand structure and genetic diversity. - Forest Ecology and Management 284: 34-44.

PRETZSCH H. 2006. Species-specific allometric scaling under self-thinning: evidence from long-term plots in forest stands. - Oecologia 146: 572-583.

REFEROWSKA-CHODAK 2014. Problematyka martwego drewna i drzew dziuplastych w systemach certyfikacji FSC i PEFC. - Studia i Materiały Centrum Edukacji Przyrodniczo-Leśnej w Rogowie 41(4): 98-115.

RYкоwski K. 2013. Przyszłość leśnictwa zaczyna się dzisiaj. - Las Polski 7: 7-9.

Socha J. 2019. Młode mogą więcej. O zmianach klimatycznych opowiada prof. Jarosław Socha. - Głos Lasu 7-8: 10-13.

StEARNS S. C. 1992. The evolution of life histories. s. xii + 249. Oxford University Press, London.

SzCZERBICKi E. 2020. Rozstrój w przyrodzie. - Las Polski 1: 8-11.

SZWAGRZYK J. 2014. Zamieranie i rozkład drzew jako procesy ekologiczne. - Studia i Materiały Centrum Edukacji Przyrodniczo-Leśnej w Rogowie 41(4): 9-14.

SzWAGRZYK J. 2019. Polski model leśnictwa wobec nowych wyzwań w szybko zmieniającym się świecie.

- W: K. Szabla (red.), Wielofunkcyjna gospodarka leśna wobec oczekiwań przemysłu drzewnego i ochrony przyrody. 119 Zjazd Polskiego Towarzystwa Leśnego w Darłówku, 12-14.09.2019. Materiały konferencji: $35-45$.

WADE R. K. 2018. Models for plant self-thinning. - Ecosphere 9(5): e02219.

WisL 2018. Wielkoobszarowa Inwentaryzacja Stanu Lasów w Polsce. Wyniki za okres 2013-2017. Etap 2.4.1.b. s. 557. Praca wykonana przez Biuro Urządzania Lasu i Geodezji Leśnej na zamówienie Dyrekcji Generalnej Lasów Państwowych. Państwowe Gospodarstwo Leśne Lasy Państwowe, Sękocin Stary.

WyŻGA B., KACZKA R. \& ZAWIEJSKA J. 2012. Zróżnicowanie depozycji grubego rumoszu drzewnego w ciekach górskich o średniej i dużej szerokości. - Prace i Studia Geograficzne 50: 159-169.

Zasady Hodowli Lasu. 2012. s. 72. Centrum Informacyjne Lasów Państwowych, Warszawa.

ZEIDE B. 1987. Analysis of the 3/2 power law of self-thinning. - Forest Science 33: 517-537.

\section{SUMMARY}

Foresters in Poland have accepted the presence of coarse woody debris (CWD) in managed forests; recent inventories confirm that the amount of CWD has been increasing. However, the rules of forest management still demand removal of any diseased tree from the forest as soon as possible. Trees invaded by bark beetles or infested by pathogenic fungi are considered a threat to forest health and are removed during sanitary 
cutting. Trees that are malformed or mechanically injured - ideal candidates for habitat trees - are also removed during forestry work. That approach is typical for timber-oriented forest management. In Poland, multifunctional forestry is the declared policy in all forests belonging to the National Forests Enterprise. The rules for managing and protecting forest stands are uniform throughout the country. Those rules were developed to ensure production of large amounts of high-quality timber. This does not allow some diseased or malformed trees to be spared as prospective habitat trees and as future sources of CWD. Without relaxation of the rules concerning sanitary cutting in managed forests in Poland it will be difficult to maintain or increase the current amount of CWD in forests. There is no point in leaving diseased or injured trees everywhere, but it is necessary in areas of high value for recreation and conservation of biodiversity. In forest districts that are not of great value for recreation or conservation, where timber production is a priority, there is no need to leave such trees. To make the rules more flexible it has to be acknowledged that forests in different areas have different priorities and cannot all be managed the same way.

Wptynęto: 15.01.2020 r.; przyjęto do druku: 04.03.2020 r. 